\title{
Complex odor control based on ozonation/ GAC advanced treatment: optimization and application in one full-scale water treatment plant
}

\author{
Ping Xia ${ }^{1,2^{*}}$, Shuangyi Zhang ${ }^{2}$, Jianwei Yu ${ }^{3}$, Hui Ye ${ }^{2}$, Dong Zhang ${ }^{2}$, Lei Jiang ${ }^{2}$, Zheng Wang ${ }^{2}$ and Daqiang Yin ${ }^{1^{*}}$
}

\begin{abstract}
Background: Taste and odor problem in drinking water is one major concern for consumers and water supply. Exploring the odor characteristics and the major odor causing compounds in the source water is the base for odor control in drinking water treatment plant (WTP). In this study, focusing on a newly constructed reservoir with Huangpu River as the source water, the occurrence of typical odorants and their variations were first identified. Correspondingly, the removal behavior in an ozone/GAC advanced treatment process was investigated.

Results: The results indicated that 2-methylisoborneol (2-MIB), geosmin (GSM), and bis (2-chloroisopropyl) ether (BCIE) have major contribution to the musty/earthy and chemical/septic odors in the source water, respectively. Pre-ozonation alone $\left(1 \mathrm{mg} \mathrm{L}^{-1}\right)$ showed limited removal for $2-\mathrm{MIB}$ and $\mathrm{BCIE}$, at less than $30 \%$ and $20 \%$, respectively, while combining with coagulation, sedimentation, and sand filtration, the removals were improved to higher than $50 \%$. After post-ozonation, the desired removal was achieved at a $1.5 \mathrm{mg} \mathrm{L}^{-1}$ dosage with all the odorants decreased below the corresponding odor threshold concentrations (OTCs) in the effluents. Furthermore, at a $1 \mathrm{mg} \mathrm{L}^{-1}$ postozone addition, by combining with subsequent GAC process, the odor problem was solved as well.

Conclusion: To resolve the odor problem in the drinking water, the concentrations of the odorants at less than their OTCs need to be achieved. As 2-MIB and BCIE have low reactivity towards direct ozonation, a subsequent GAC is needed with a moderate dosage of post-ozonation $\left(1 \mathrm{mg} \mathrm{L}^{-1}\right)$. Thus, for the odor problem in the source water, the suggested operation is: $1 \mathrm{mg} \mathrm{L}^{-1}$ of pre-ozonation in combination with coagulation, sedimentation, and sand filtration, followed by a $1 \mathrm{mg} \mathrm{L}^{-1}$ dosage of post-ozonation and finished by a GAC process.
\end{abstract}

Keywords: Odor, Ozonation, Granular activated carbon, 2-Methylisoborneol, Bis(2-chloroisopropyl) ether

\section{Background}

Ensuring the esthetic satisfaction in drinking water is one major objective for water utilities. Usually, the occurrence of most odor issues was reported to associate with source water problems. For example, the bloom of algae

*Correspondence: shoppingone123@hotmail.com; yindq@tongji.edu.cn ${ }^{1}$ Key Laboratory of Yangtze River Water Environment, Ministry of Education, College of Environmental Science and Engineering, Tongji University, Shanghai 200092, China

Full list of author information is available at the end of the article resulting from the excess of nutrients is one of the internal causes that leads to the production of the odorous metabolites [51]. Additionally, contaminant inputs such as tributaries, upstream industrial discharges, and oil spills from gas station lead to the external causes for the odor problem in the surface water [21, 25, 32]. Odor and taste compounds although have been reported to be nontoxic towards humans with the concentrations observed in the environment, their effects on public trust on drinking water safety is significant. In China, odor issue has become one growing concern for water safety, especially 
after the water crisis in Wuxi in 2007 [67], where serious complex odorants occurred in Lake Taihu water source. However, due to the limited information on odor characteristics and specific odor causing compounds, water treatment plants (WTPs) were usually not able to adopt applicable measures while encountering taste and odor problems.

Musty/earthy odor caused by the presence of 2-methylisoborneol (2-MIB) and geosmin (GSM) is the most encountered problem in drinking water, which is usually related with cyanobacteria proliferation $[26,33,47]$, especially some benthic cyanobacteria such as Oscillatoria and Phormidium [56]. Huangpu River, the major source water in Shanghai, China, was reported to face musty/ earthy odor problems seasonably, which was mainly correlated to 2-MIB produced by Phormidium [46]. Besides Oscillatoria and Phormidium, Pseudanabaena species have been reported to be a potential GSM producer [23].

Compared to musty/earthy odor compounds, the compounds that cause the chemical/swampy/septic smells are more complicated. A large number of compounds may result in an unpleasant odor in the surface water. Some sulfur-based odor may result from anaerobic bacteria $[6,9,41]$. For example, thiols (e.g., methanethiol) and thioether are the primary swampy/septic odor sources $[16,64]$, while thioether includes not only mono-sulfide thioether (e.g., dimethyl sulfide, diethyl sulfide, and dipropyl sulfide), but also multi-sulfide thioether (e.g., dimethyl disulfide (DMDS), dimethyl trisulfide (DMTS), and diethyl disulfide). Other odorous compounds (e.g., benzenes, phenols, esters, and heterocyclic compounds containing oxygen), arising from industrial activities such as meat rendering, rubber proofing, resin and plastic synthesis, and dye manufacturing, may cause odor problem at a very low concentration $\left(\mathrm{ng} \mathrm{L}^{-1}\right)[11,12,42$, 43]. For example, bis(2-chloroisopropyl) ether (BCIE) is a chemical that is primarily used in industry as a solvent for fats, waxes and greases, as an extractant in paint and varnish removers, in spotting and cleaning solutions, and in textile processing [14]. Chemical/septic smelling compounds resulting from the industrial discharge and surface runoff [62], together with the natural odorous compounds (e.g., MIB and GMS) form the complex odor in the surface water. Complex odorants have been reported to be present in Huangpu River [17], causing a seasonal odor issue.

Conventional treatment processes showed a limited odorant removal. Pre-treatment, advanced treatment, or a combination of these techniques have been reported to improve the removal efficiency [39]. Compared to chlorination and potassium permanganate $\left(\mathrm{KMnO}_{4}\right)$, ozonation revealed a greater removal efficiency [29, 30, 48]. Oxidation is effective to treat thiols and thioethers as well as the musty/earthy and chemical odorous compounds [53]. However, the byproducts from ozonation such as bromide ions, precursor of aldehydes, ketones, and carboxylic acids cannot be neglected. Generally, granular activated carbon (GAC) is applied in combination with ozonation to remove the byproducts and the odorant residuals [28]. Studies have indicated that GAC was effective in removing musty/earthy compounds 2-MIB and GSM [13, 63]. A decreasing effectiveness was observed for the typical septic odorous compounds including thiols and thioethers through GAC [2]. By applying postozonation in combination with GAC, the odorants may be eliminated through oxidation and physiochemical adsorption. Adding pre-ozonation prior to post-ozonation and GAC improved the removal efficiency of recalcitrant compounds (e.g., emerging contaminants) [45, 65]. Such combination of treatment processes may apply to complex odor elimination when there is a significant input of the odorous compounds in the source water. Currently, the combined processes that are commonly involved include: (1) post-ozonation followed by GAC; and, (2) pre-ozonation, followed by post-ozonation, and $\operatorname{GAC}[17,31]$.

A number of studies have focused on the odorant removal in water treatment processes. Ozonation and GAC were the most investigated unit processes $[4,8$, $13,20,38,40]$ as well as the $\mathrm{O}_{3} /$ GAC combined process $[1,39]$. For the most part of these studies, great efforts have been made on the effectiveness of an individual process, while the addictive and synergistic effects of a full treatment train have obtained less consideration. A few studies have investigated the effectiveness of a complete treatment train; however, the experiments were conducted in well controlled pilot systems. For example, Chen et al. [10] examined the removal of 2-MIB and GSM in a pilot-scale treatment train (including coagulation, sand filtration, ozonation, and GAC) where the odorants were spiked with pre-determined concentrations and the influent water quality was relatively stable. Moreover, the complex odor control has received less attention as well. For the above reasons, current study investigated and optimized an existing WTP treatment train reflecting real water conditions to achieve a simultaneous removal of a group of complex odorants.

Jinze Reservoir is a newly constructed reservoir, which is located at the upstream of Huangpu River, in Shanghai, China. The potential complex odor problem, especially during the startup period, needs to be evaluated; more importantly, an effective and practical control method needs to be developed. This study characterized the various odorants being present in the reservoir. The primary odor contributors were identified as well. The operation of the existing ozonation/GAC processes applied in one 
downstream WTP was evaluated and optimized based on the practicable operational conditions. The application of the optimized treatment train was evaluated for 6 months to further verify its efficiency on complex odor control. This study provides a feasible odor elimination solution for the full-scale WTPs facing a potential complex odor issue.

\section{Materials and methods}

\section{Chemicals and reagents}

Odorant standards were ordered from Sigma-Aldrich (USA) with purity greater than $95 \%$. A stock solution was prepared in methanol at a concentration of $10 \mathrm{mg} \mathrm{L^{-1 }}$ for each reference compound (Table 1). Analytical grade of sodium chloride $(\mathrm{NaCl})$ and anhydrous sodium sulfate $\left(\mathrm{Na}_{2} \mathrm{SO}_{4}\right)$ were purchased from

Table 1 Information of 13 investigated odorants

\begin{tabular}{|c|c|c|c|}
\hline Odorants & Odor description & OTC $\left(\mu \mathrm{g} \mathrm{L}^{-1}\right)^{\mathrm{a}, \mathrm{b}}$ & $\begin{array}{l}\text { Observed } \\
\text { range } \\
\left(\mu \mathrm{gL}^{-1}\right)^{c}\end{array}$ \\
\hline DMDS & Swampy, septic & 0.03 & $0.67-82.70$ \\
\hline DMTS & Swampy, septic & 0.01 & $0.23-1.59$ \\
\hline Hexanal & Herbal/flavor/almond & 4.5 & $0.43-30.99$ \\
\hline $\mathrm{EB}$ & Plastic/oily/chemical & 150 & $0.05-56.60$ \\
\hline BA & Herbal flavor & 4.5 & $3.26-251.62$ \\
\hline $1,4-\mathrm{DCB}$ & Almond/sweet & 4.5 & $0.19-19.26$ \\
\hline $\mathrm{BClE}$ & $\begin{array}{l}\text { Chemical/swampy/ } \\
\text { septic }\end{array}$ & 0.10 & $6.93-900.29$ \\
\hline 2-MP & Medicinal odor & 14.73 & $2.76-4.81$ \\
\hline 3-MP & Medicinal odor & 12.89 & $3.82-20.94$ \\
\hline 2-MIB & Musty & 0.005 & $0.14-35.48$ \\
\hline 2,4-Decadienal & Fishy/oily & 0.029 & $2.76-21.04$ \\
\hline Indole & Stink & 0.10 & $6.88-30.24$ \\
\hline GSM & Earthy & 0.004 & $0.25-15.43$ \\
\hline \multicolumn{4}{|l|}{ a [18] } \\
\hline \multicolumn{4}{|l|}{${ }^{b}[55]$} \\
\hline
\end{tabular}

Beijing Chemicals Ltd., China. Both chemicals $(\mathrm{NaCl}$ and $\mathrm{Na}_{2} \mathrm{SO}_{4}$ ) were pre-baked in a furnace at a temperature of $450{ }^{\circ} \mathrm{C}$ for $2 \mathrm{~h}$ to removal possible organics and moisture. A Milli-Q purification system was used to provide ultrapure water $(18.2 \mathrm{M} \Omega \mathrm{cm})$ for chemical preparations.

\section{Sampling site and collection}

Jinze Reservoir is an upstream water source on Huangpu River with a total volume of 9.1 million $\mathrm{m}^{3}$ and a water supply capacity of 3.51 million $\mathrm{m}^{3}$ day $^{-1}$, serving 6.7 million residents from five districts in the southwest part of Shanghai, China. The reservoir started its operation in late 2016. The raw water had a chemical oxygen demand at 3.01 to $4.48 \mathrm{mg} \mathrm{L}^{-1}$. Serving as the source water of the downstream WTP, the occurrence of odorous compounds in the reservoir effluents were monitored monthly from January 2017 to December 2018 to identify their potential threats. In total, 13 compounds were selected for evaluation (Table 1), which was identified as the potential odorants in a previous study [18].

Xin Che Dun (XCD) WTP is a newly built WTP operating from March 2018. Taking Jinze Reservoir as its source water, XCD has a treatment capacity of $160,000 \mathrm{~m}^{3}$ day $^{-1}$. Detailed operating parameters are listed in Table 2. From April 2018 to July 2018, samples were collected weekly from the plant influents and the effluents after each unit process (pre-ozonation, sedimentation, filtration, post-ozonation, GAC, and clean water basin) to evaluate the removal efficiency.

All water samples were collected in $500 \mathrm{~mL}$ amber glass bottles that were pre-washed using nonphosphate laboratory-grade detergent solution (Liquinox $^{\mathrm{TM}}$ ) and thoroughly rinsed with deionized (DI) water to remove detergent residue [3, 52]. $200 \mathrm{~mL}$ of the sample was used for flavor profile analysis (FPA), and $10 \mathrm{~mL}$ was prepared for determining the odorant concentrations. All analyses were completed within $24 \mathrm{~h}$ after sample collection.

Table 2 Operating parameters in the water treatment plant

\begin{tabular}{|c|c|c|c|c|c|}
\hline Process & $\begin{array}{l}\text { Designed contact } \\
\text { time (min) }\end{array}$ & $\begin{array}{l}\text { Coagulant (aluminum sulfate) } \\
\text { concentration }\left(\mathrm{mg} \mathrm{L}^{-1}\right)^{\mathrm{a}}\end{array}$ & $\begin{array}{l}\text { Ozone dosage } \\
\left(\mathrm{mg} \mathrm{L}^{-1}\right)^{\mathrm{a}}\end{array}$ & $\begin{array}{l}\text { Actual contact } \\
\text { time (min) }\end{array}$ & Backwash frequency \\
\hline Pre-ozonation & 3 & - & $0-1.0$ & 3.4 & - \\
\hline Flocculation & 20 & $20-30$ & - & 23 & - \\
\hline Sedimentation & 120 & - & - & 137 & - \\
\hline Sand filtration & 30 & - & - & 34 & $24-48 h$ \\
\hline Post-ozonation & 12 & - & $0-1.5$ & 14 & - \\
\hline GAC & 12 & - & - & 14 & 5-10 days \\
\hline
\end{tabular}

a Coagulant concentration and ozone dosage may vary according to the actual influent qualities 


\section{Sensory evaluation of odor}

Flavor profile analysis (FPA) was adopted for odor characterization [61]. A panel with five panelists identified each odor attribute and its intensity based on a sevenpoint intensity scale (1: odor threshold; 2 and 4: very weak to weak odor; 6 and 8: moderate odor; 10 and 12: strong odor). Flasks (500 mL) containing $200 \mathrm{~mL}$ of water sample were heated to $45^{\circ} \mathrm{C}$ in a water bath prior to the analysis. During the evaluation, each panelist held the bottom of the flask with one hand, opened the glass stopper with the other hand, smelled the samples; and recorded the description and intensity of each sample. The result of each sample was finalized after a consensus had been reached in the panel.

\section{Quantification of odorants}

Analyses of samples were accomplished with solid phase microextraction (SPME) followed by gas chromatography tandem mass spectrometry (GC-MS/MS) with a triple quadrupole instrument (Shimadzu GCMSTQ8050 NX) [27]. In total, 13 odorants were analyzed including the earthy/musty odor substances 2-MIB and GSM as well as the chemical and septic odorants (sulfides, BCIE, and other aromatics and aldehydes) (Table 1). Water sample $(10 \mathrm{~mL})$ was added to a $20 \mathrm{~mL}$ CTC vial that was preloaded with $2.5 \mathrm{~g}$ of $\mathrm{NaCl}$. The SPME fiber was inserted to the vial for extraction. The extracted substances were injected to the GC column (Agilent VF-624MS; $0.32 \mathrm{~mm} \times 1.80 \mu \mathrm{m} \times 60 \mathrm{~m}$ ) in splitless mode for separation with a $1 \mathrm{~mL} \mathrm{~min}^{-1}$ carrier gas flow. The inlet temperature was set to be $250{ }^{\circ} \mathrm{C}$. With an initial temperature of $40{ }^{\circ} \mathrm{C}$, the column temperature was ramped $8{ }^{\circ} \mathrm{C} \mathrm{min}-1$ to $260{ }^{\circ} \mathrm{C}$ with a $10 \mathrm{~min}$ hold. The temperatures of the quadrupole and the ion source were $150{ }^{\circ} \mathrm{C}$ and $230{ }^{\circ} \mathrm{C}$, respectively. The selective ion monitoring (SIM) mode was employed in the quantitative analyses [66]. The qualification of the targeted odorant was based on its retention time, ion fragmentation, and the corresponding abundance [15, 54]. The concentration of the odorant was calculated using the calibration curve generated by the workstation with a range of external standards and their corresponding peak areas.

\section{Odor activity value (OAV)}

OAV was used to evaluate the contribution of the odor from each odorant. The value of OAV was calculated by dividing the measured concentration by its corresponding OTC. Odorants with OAVs at equal to or greater than one contribute greatly to the odor profile, while a value at less than one indicates a limited contribution [17].

\section{Results and discussion}

\section{Odor characterization and odorant identification in source} water

Table 1 shows the results of the 13 targeted odorants in the WTP source water. As indicated, the concentration of 2-MIB increased in summer and autumn when algal blooms occurred relatively often. In this study, 2-MIB in Jinze Reservoir was approximately $100 \mathrm{ng} \mathrm{L}^{-1}$ in August 2017 (Fig. 1), which is 20 times greater than its OTC (Table 1). GSM was detected in over $80 \%$ of the samples with approximately $40 \%$ exceeding the OTC (4 $\left.\mathrm{ng} \mathrm{L}^{-1}\right)$. As an industrial chemical, BCIE was detected in all samples with relative high concentrations. Other odorants that were detected in more than $50 \%$ of the samples included thioethers (i.e., DMDS), aldehydes (i.e., hexanal and benzaldehyde (BA)), and benzenes (i.e., ethylbenzene (EB) and 1,4-dichloro-benzene (1,4-DCB)). Similarly to BCIE, the occurrence of these compounds may be related to industrial activities and discharges. For example, DMDS is a widely used soil fumigant [49] and can be produced in industrial process such as the wood-pulp industry and oil refineries [22]. DMDS was observed in swine facilities [35] as well. BA is related to the production of food preservatives, pharmaceuticals, and cosmetics [50]. EB is mostly used in producing styrene [5]. The presence of the various odorants in Jinze Reservoir is not surprising, as Huangpu River has long been reported to have issues regarding complex odorants $[18,46,60]$. Guo et al. [18] indicated that DMDS and BCIE were observed to be the primary contributors for chemical/septic smell, while 2-MIB and GSM contribute the most for musty/earthy odor. The complex odor issue in Huangpu River was also observed by Yang et al. [60] and Guo et al. [19], where nine odorous compounds belonging to benzenes, ethers, pyrazines, thioethers, and heterocyclic compounds were detected.

All targeted odorants were detected in the reservoir to some extent ( 0.05 to $900.29 \mathrm{ng} \mathrm{L}^{-1}$ ) (Table 1 ); their corresponding OAVs were calculated to further identify the compounds that contributed the most to the odor profile (Fig. 2). GSM and 2-MIB were observed to be the major earthy/musty odor contributor in Jinze, while BCIE and sulfide compounds such as DMDS were responsible for the chemical/septic odor. BCIE obtained an average OAV at as high as 2.97, which may result from its greater concentration (averaged at $297.18 \mathrm{ng} \mathrm{L}^{-1}$ ) compared to other odorous compounds. With an OTC at $5 \mathrm{ng} \mathrm{L}^{-1}, 2-\mathrm{MIB}$, on the other hand, still showed an OAV at greater than one despite a relative low concentration (approximately averaged at $6 \mathrm{ng} \mathrm{L}^{-1}$ ). Compounds with low OTCs, though may have low detected concentration, cannot be neglected from odor concern. Moreover, seasonal effect needs 


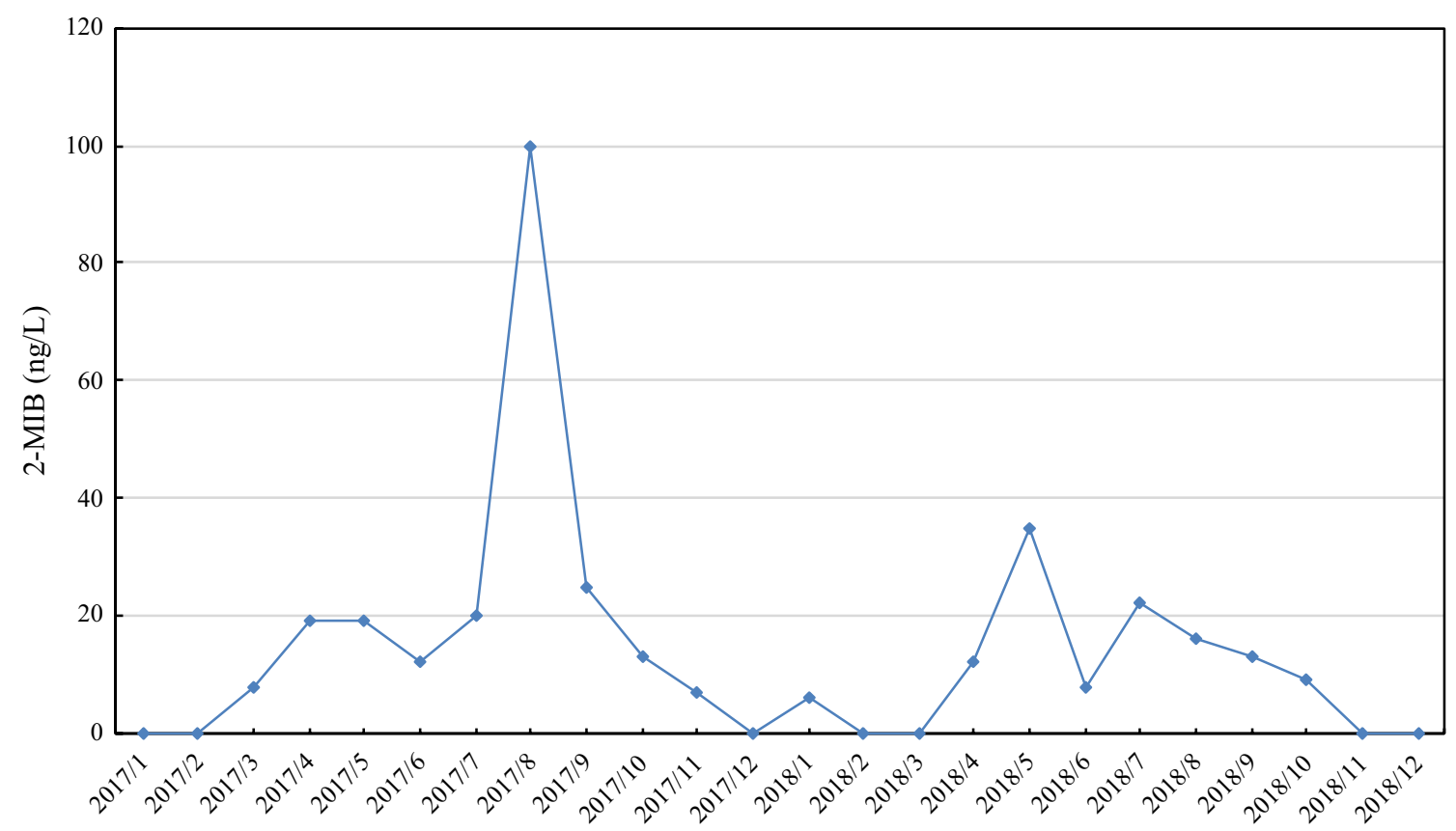

Fig. 1 Concentration of 2-MIB in Jinze Reservoir from January 2017 to December 2018. A spike in 2-MIB concentration in August 2017 may relate to an algal bloom event

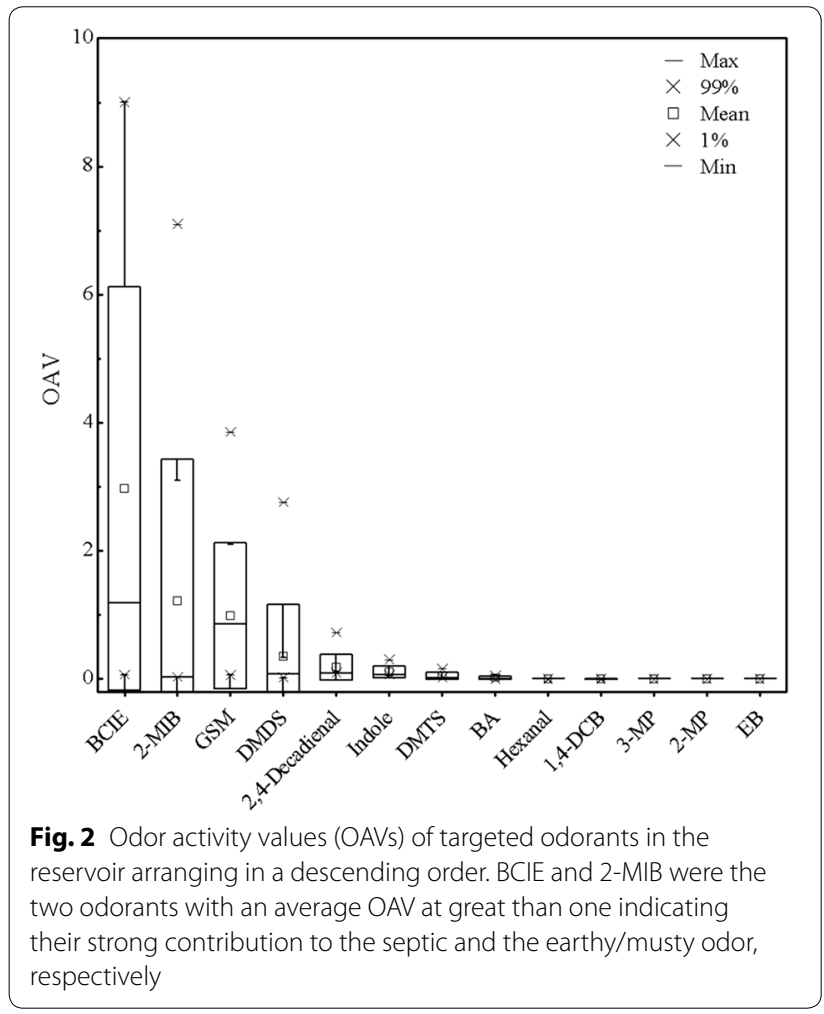

to be taken into account as well. For example, greater 2-MIB concentrations in summer (Fig. 1) reflected a potential off-flavor event. Other odorous compounds including DMDS and DMTS, 2,4-decadienal, indole, and BA, contributed to septic, fishy, stinky, and herbal flavor odors, respectively (Table 1 and Fig. 2); these compounds together formed a very complex odor in the source water.

\section{Removal of odorous compounds in XCD WTP Preliminary evaluation of odor elimination}

FPA was conducted to preliminarily evaluate the complex odor control efficiency in the WTP (Fig. 3). Source water showed an average odor intensity of eight indicating a moderate odor and the need for odor control. Compared to no pre-oxidation condition, application of pre-ozonation improved the odor reduction. Specifically, with a dosage of $0.5 \mathrm{mg} \mathrm{O}_{3} \mathrm{~L}^{-1}$, FPA intensity of the source water was reduced to seven. Further increasing the dosage to $1 \mathrm{mg} \mathrm{O}_{3} \mathrm{~L}^{-1}$, the intensity decreased to six. By combining subsequent coagulation and sedimentation process, the FPA intensity decreased to four, indicating a weak odor (Fig. 3). Greater performance was achieved after sand filtration with the intensity reduced to the threshold value (i.e., 1). Although pre-ozonation alone revealed some reduction in odor intensity, to reduce the intensity to an odor-free level, a combined process that involves additional advanced treatment such as postozonation and GAC needs to be considered. As 2-MIB and $\mathrm{BCIE}$ were the two major odor contributors, their removal efficiencies were investigated through the WTP 


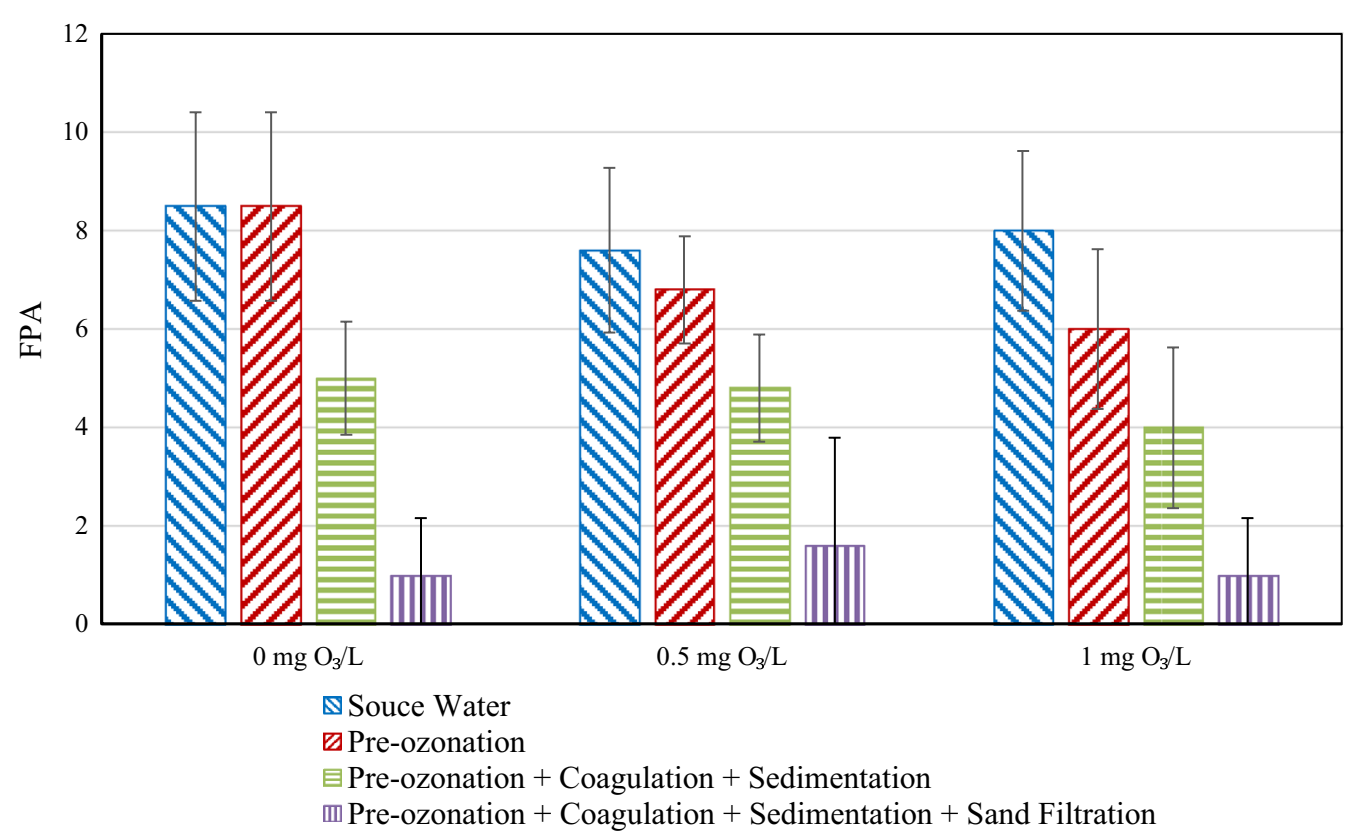

Fig. 3 Evaluation of the FPA in the source water and after each unit treatment process in XCD WTP. The dosage of pre-ozonation was demonstrated on the $X$ axis. FPA odor intensity at 0 indicates odor-free samples; at 1 indicates the odor threshold; at 2 to 4 indicates a very weak to weak odor; at 6 to 8 indicates a moderate odor; and at 10 to 12 indicates a strong odor

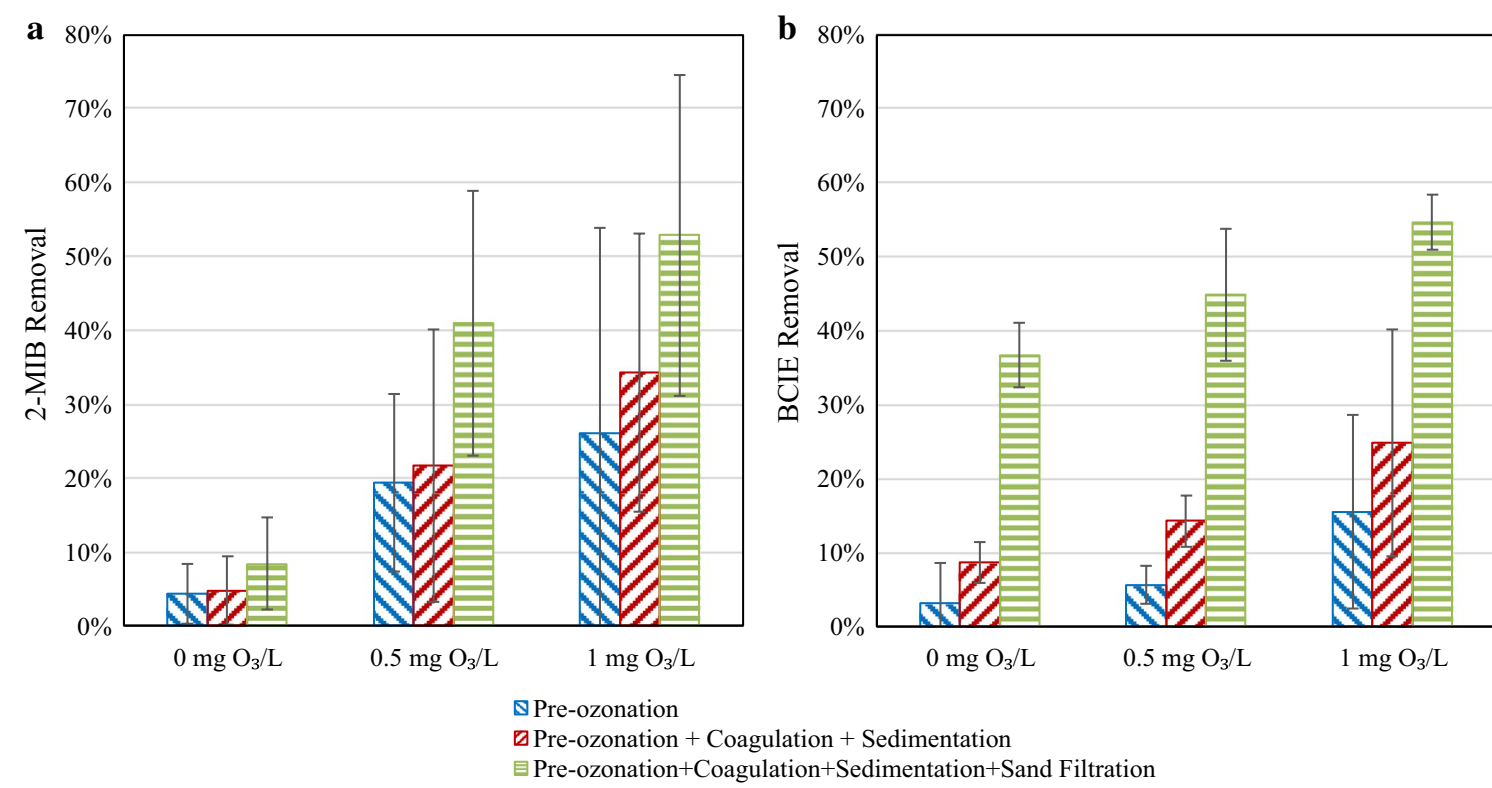

Fig. 4 Removal of $\mathbf{a}$ 2-MIB and $\mathbf{b}$ BCIE shown as a function of pre-ozonation dosages. The removal efficiency of pre-ozonation alone was compared with a combined treatment process (i.e., pre-ozonation followed by coagulation, sedimentation, and sand filtration). Odorant removal in pre-ozonation alone with a zero dosage was due to the application of powdered activated carbon $\left(10 \mathrm{mg} \mathrm{L}^{-1}\right)$ at the intake of the source water (i.e., a pre-treatment process for the WTP)

to evaluate the odor reduction and optimize the applicable operational conditions in the existing water treatment facilities (Figs. 4 and 5).

\section{Evaluation of pre-ozonation for odor removal}

Removal of 2-MIB was less than $5 \%$ without the pre-ozonation (Fig. 4a). With subsequent treatment processes 

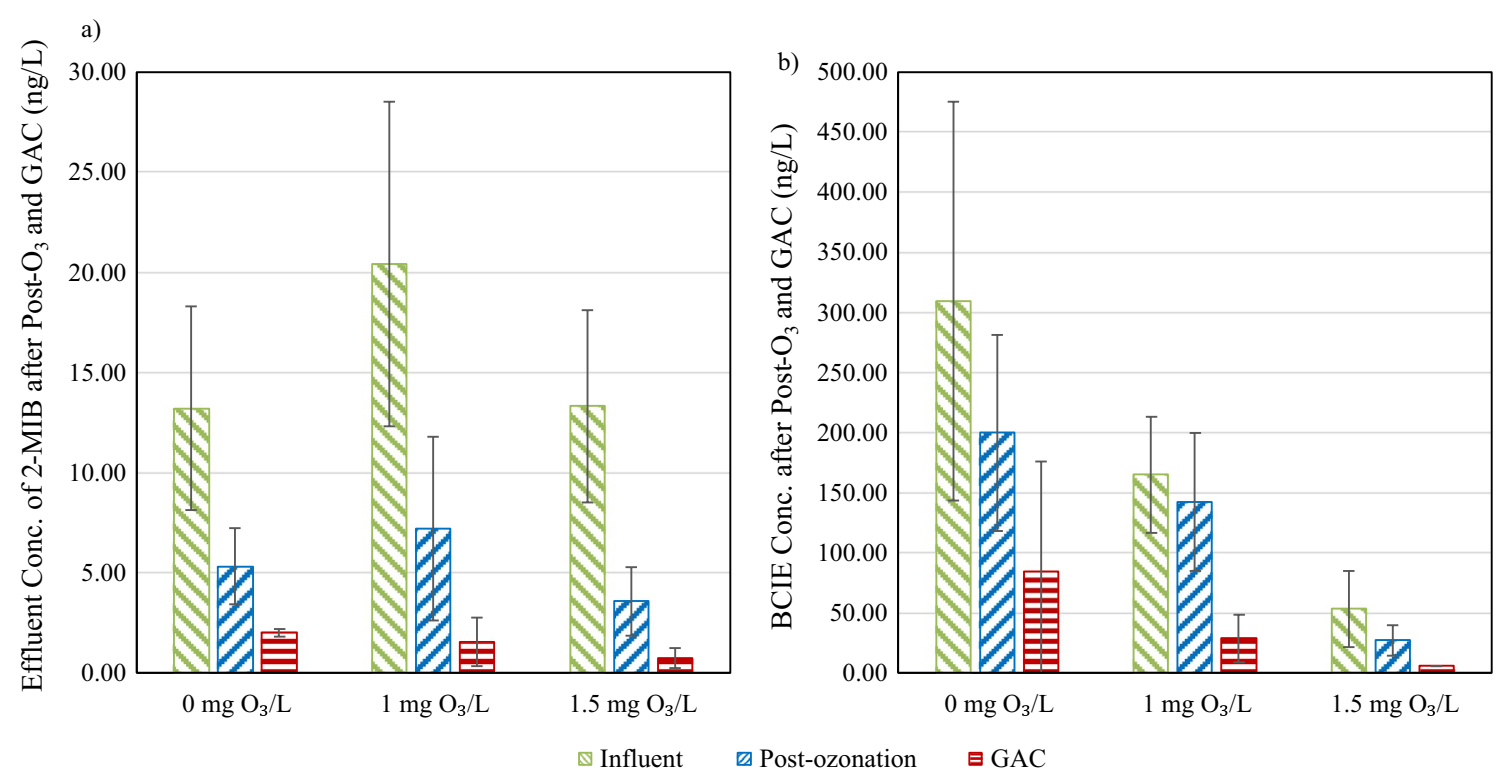

Fig. 5 Effluent concentration of $\mathbf{a} 2-\mathrm{MIB}$ and $\mathbf{b}$ BCIE from post-ozonation and GAC in XCD WTP; their average influent concentrations were shown as well for comparison

(i.e., coagulation, sedimentation, and sand filtration), the overall removal was still less than $10 \%$, indicating the need to apply pre-ozonation. Pre-ozonation was investigated with dosages of $0.5 \mathrm{mg} \mathrm{L}^{-1}$ and $1 \mathrm{mg} \mathrm{L}^{-1}$, which are the typical dosages applied in XCD WTP. Generally, increasing the dosage of pre-ozonation demonstrated a greater removal. Specifically, removal increased to $19 \%$ with a $0.5 \mathrm{mg} \mathrm{L}^{-1}$ pre-ozonation dosage, and further improved to $26 \%$ with a dosage of $1 \mathrm{mg} \mathrm{L}^{-1}$. Limited removals were also observed in a pilot plant study conducted by Yang et al. [60], where 2-MIB removal was approximately $20 \%$ and $30 \%$ with a pre-ozonation dosage of $0.5 \mathrm{mg} \mathrm{L}^{-1}$ and $1 \mathrm{mg} \mathrm{L}^{-1}$, respectively. Natural organic matters (NOMs) in water consumed the ozone and $\mathrm{OH}$. and inhibited the oxidation of the odorants [59]. Pre-ozonation targeted mostly on the NOMs and revealed a competing effect on 2-MIB removal during degradation [65]. Xie et al. [59] observed a significant effect on the odorant reduction when $\mathrm{NOM}$ exceeded $1 \mathrm{mg} \mathrm{L}^{-1}$. With an influent total organic carbon (TOC) ranging from 3.03 to $4.00 \mathrm{mg} \mathrm{L}^{-1}$ and an average turbidity at $19.35 \pm 4.20 \mathrm{NTU}$ in current study, 2-MIB was not effectively removed.

Coagulation and sedimentation have been reported to be ineffective in removing odorants [44]. However, adding a pre-oxidation and a subsequent filtration may improve the overall removals [10]. In this study, pre-ozonation in combination with coagulation, sedimentation, and sand filtration achieved an average reduction of $41 \%$ with a pre-ozonation dosage of $0.5 \mathrm{mg} \mathrm{L}^{-1}$ and an average removal at $52 \%$ with a dosage of $1 \mathrm{mg} \mathrm{L}^{-1}$ (Fig. 4a). Preozonation broke down the large organic molecules (e.g., odorants such as 2-MIB) which may enhance their electrostatic interactions with coagulant flocs [36]. Though the combined treatment revealed an improvement, the removal was still insufficient as the effluent concentration of 2-MIB from the sand filtration was $5.60 \pm 2.09 \mathrm{ng} \mathrm{L}^{-1}$, which is greater than its OTC.

Similar trends were observed in BCIE removals. Consistent with other studies [60], even though an improved reduction of BCIE was observed with an increasing pre-ozonation dosage, the removal was still limited (Fig. 4b). Specifically, removal increased from 3 to $6 \%$ with a $0.5 \mathrm{mg} \mathrm{L}^{-1}$ dosage, and further improved to $15 \%$ with a dosage of $1 \mathrm{mg} \mathrm{L}^{-1}$. BCIE was relatively resistant to pre-ozonation as the removal was less than $20 \%$ with the greatest dosage; again the presence of NOM in the source water decreased the potential of ozonation to target on the odorants. Similarly, the combined treatment, i.e., ozonation followed by coagulation, sedimentation, and sand filtration, showed limited improvement. Greatest removal (i.e., 55\%) was observed at the highest ozone dosage. However, with an effluent concentration of $152.40 \mathrm{ng} \mathrm{L}^{-1}$ in the sand filtration, BCIE still exceeded the OTC after a series of treatment units. As both concentrations of 2-MIB and BCIE remained above their olfactory perception thresholds, the optimal dosage of pre-ozonation was set to be $1 \mathrm{mg} \mathrm{L}^{-1}$ (i.e., the greatest dosage in the applicable range of the WTP) and 
the optimization of the post-ozonation dosage was performed based on this dosage.

\section{Evaluation of post-ozonation for odor removal}

The dosages of post-ozonation again were selected based on the typical operational range in XCD (i.e., $0.8 \mathrm{mg} \mathrm{L}^{-1}$ to $1.5 \mathrm{mg} \mathrm{L}^{-1}$ ) used in the full-scale WTP. 2-MIB concentration was reduced to below the OTC with a post-ozonation dosage of $1.5 \mathrm{mg} \mathrm{L}^{-1}$ (Fig. 5a).

Compared to $1.5 \mathrm{mg} \mathrm{L}^{-1}$, a dosage of $1 \mathrm{mg} \mathrm{L}^{-1}$ did not show an acceptable effluent concentration $\left(>5 \mathrm{ng} \mathrm{L}^{-1}\right)$, because the 2-MIB in the influent was two times greater (up to approximately $30 \mathrm{ng} \mathrm{L}^{-1}$ ) on the day of sampling. Influent concentration affected the treatment efficiency significantly (Fig. 5a) [24, 39]. With a dosage of $1 \mathrm{mg} \mathrm{O} \mathrm{O}_{3} \mathrm{~L}^{-1}$, Park et al. [39] observed a removal of less than $80 \%$, when the influent 2-MIB concentration was $50 \mathrm{ng} \mathrm{L}^{-1}$; this removal increased to greater than $95 \%$ when a $1.5 \mathrm{mg} \mathrm{L}^{-1}$ of ozonation was applied. 2-MIB is an aliphatic alcohol with a bicyclic structure. The hydroxyl group $(-\mathrm{OH})$ attaching on the alkyl ring acts as an electron-withdrawing group. As compounds with no aromatic moieties but containing electron-withdrawing functional group are resistant to direct ozonation [58], 2-MIB was observed to be recalcitrant. The low reactivity was indicated by the low ozone rate constant $\left(\mathrm{k}_{\mathrm{O}_{3}}=0.35\right.$ to $10 \mathrm{M}^{-1} \mathrm{~s}^{-1}$ ) as well $[40,57]$. Ozone is a selective oxidant with rate constant ranging from $10^{-1}$ to $10^{6} \mathrm{M}^{-1} \mathrm{~s}^{-1}$ $[65,68]$ while hydroxyl radical $(\mathrm{OH} \cdot)$ is less selective with rate constant $\left(\mathrm{k}_{\mathrm{OH}}\right)$ differing by less than one order of magnitude [58]. An indirect reaction with $\mathrm{OH}$. may dominate over the ozone during 2-MIB oxidation. Westerhoff et al. [57] reported the $\mathrm{k}_{\mathrm{OH}}$ ranging from $1 \times 10^{9}$ to $6 \times 10^{9} \mathrm{M}^{-1} \mathrm{~s}^{-1}$ for 2 -MIB in bulk water samples that were collected from five different surface water locations; similar results were observed by $\mathrm{Ma}$ et al. [34] as well. $\mathrm{OH}$. acted as the most significant reactive species during the degradation of the odorants in the ozonation process. $\mathrm{OH}$. is generated from the decay of ozone in water. As a result, when the influent concentration of 2-MIB was high, a moderate dosage of post-ozonation $\left(1 \mathrm{mg} \mathrm{L}^{-1}\right)$ did not produce an adequate amount of $\mathrm{OH}$. to oxidize the recalcitrant compound. In such case, a greater dosage (i.e., $1.5 \mathrm{mg} \mathrm{L}^{-1}$ ) or a subsequent advanced process (i.e., GAC) is needed, as the concentration of $\mathrm{OH}$. increases with a greater ozone dosage [57].

Similarly, the greatest BCIE removal efficiency was obtained with a $1.5 \mathrm{mg} \mathrm{L}^{-1}$ dosage. After adding the post-ozonation, the effluent concentration was reduced to $26.74 \mathrm{ng} \mathrm{L}^{-1}$, below the OTC (Fig. 5b). Compared to the results without post-ozonation, adding $1 \mathrm{mg} \mathrm{L}^{-1}$ ozone though revealed a greater reduction in BCIE, the $142.21 \mathrm{ng} \mathrm{L}^{-1}$ effluent concentration was still above the
OTC (100 ng L $\left.{ }^{-1}\right)$. Again, when the upstream has a sudden spike in odorant concentration, the moderate postozonation dosage in the WTP would not satisfy the odor requirement. BCIE is an aliphatic compound with two chlorine functional groups; these two polar groups are electron-withdrawing and leads to a low reactivity towards ozone [7]. With the source water concentration at up to approximately $500 \mathrm{ng} \mathrm{L}^{-1}$, a $1.5 \mathrm{mg} \mathrm{L}^{-1}$ dosage of post-ozonation is recommended for treating BCIE. Otherwise, with a moderate post-ozonation dosage, a subsequent process for the removal of the remaining BCIE is necessary.

\section{Suggestions for complex odor control}

To remove the complex odors simultaneously, all the odorants need to be removed below their OTCs. As discussed above, a post-ozonation dosage of $1 \mathrm{mg} \mathrm{L}^{-1}$ is insufficient to remove the complex odorants when a peak influent concentration is observed. The effectiveness of ozonation was significantly affected by the influent conditions. However, after GAC process (size: $8 \times 30$ Mesh; empty bed contact time (EBCT): 14 min; filter velocity: $10 \mathrm{~m} \mathrm{~h}^{-1}$ ), all the odorant compounds were removed to below the OTCs regardless of the source water conditions (Fig. 5). Consistent with other studies [17, 39, 60, 63], GAC was applicable for removing odorants with a wide range of influent concentration $\left(10^{0}\right.$ to $\left.10^{2} \mathrm{ng} \mathrm{L}^{-1}\right)$. But breakthrough of the GAC needs to be considered. Post-ozonation prior to GAC was observed to improve the breakthrough time as well as increase the removal efficiency in GAC [37]. Therefore, using GAC as the final polishing step, a post-ozonation $\left(1 \mathrm{mg} \mathrm{O}_{3} \mathrm{~L}^{-1}\right)$ was selected for the optimal treatment train to save the cost and minimize the ozonation byproducts (i.e., pre-ozonation $\left(1 \mathrm{mg} \mathrm{O}_{3} \mathrm{~L}^{-1}\right)+$ coagulation + sedimentation + sand filtration + post-ozonation $\left(1 \mathrm{mg} \mathrm{O}_{3} \mathrm{~L}^{-1}\right)+\mathrm{GAC}$ (EBCT: $14 \mathrm{~min})$ ), while at the same time a desirable performance of complex odor control was also achieved.

\section{Continuous operation for verification}

The optimal treatment train was operated continuously for 6 months to verify the performance of the complex odor control in XCD (Fig. 6). The results indicated that the natural odorants (2-MIB and GSM) were removed at greater than $99 \%$ and $98 \%$, respectively, both below their odor thresholds (Fig. 6a). The optimal treatment train demonstrated a good removal for BCIE (ether), the major chemical/septic odor contributor as well. A removal of $23 \%$ and $72 \%$ was achieved in pre- and post-ozonation, respectively, the GAC further ensured a $92 \%$ reduction, achieving a desirable effluent concentration for BCIE (Fig. 6b). After the treatment, indole was not detected in the effluent (Fig. 6b). Aldehydes (2,4-decadienal and 

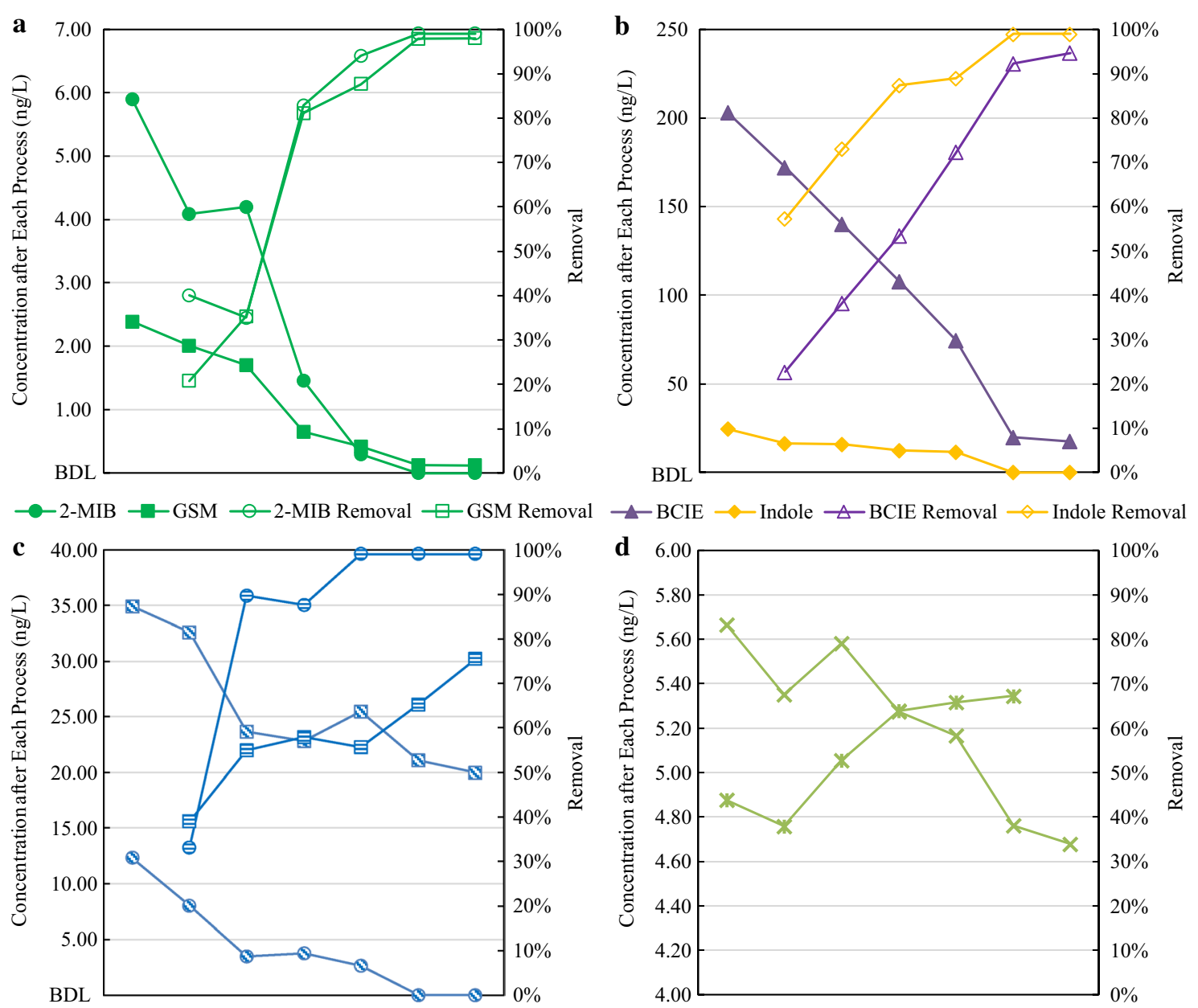

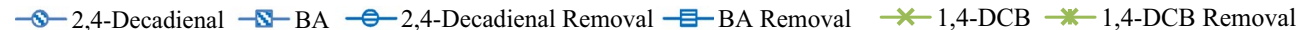
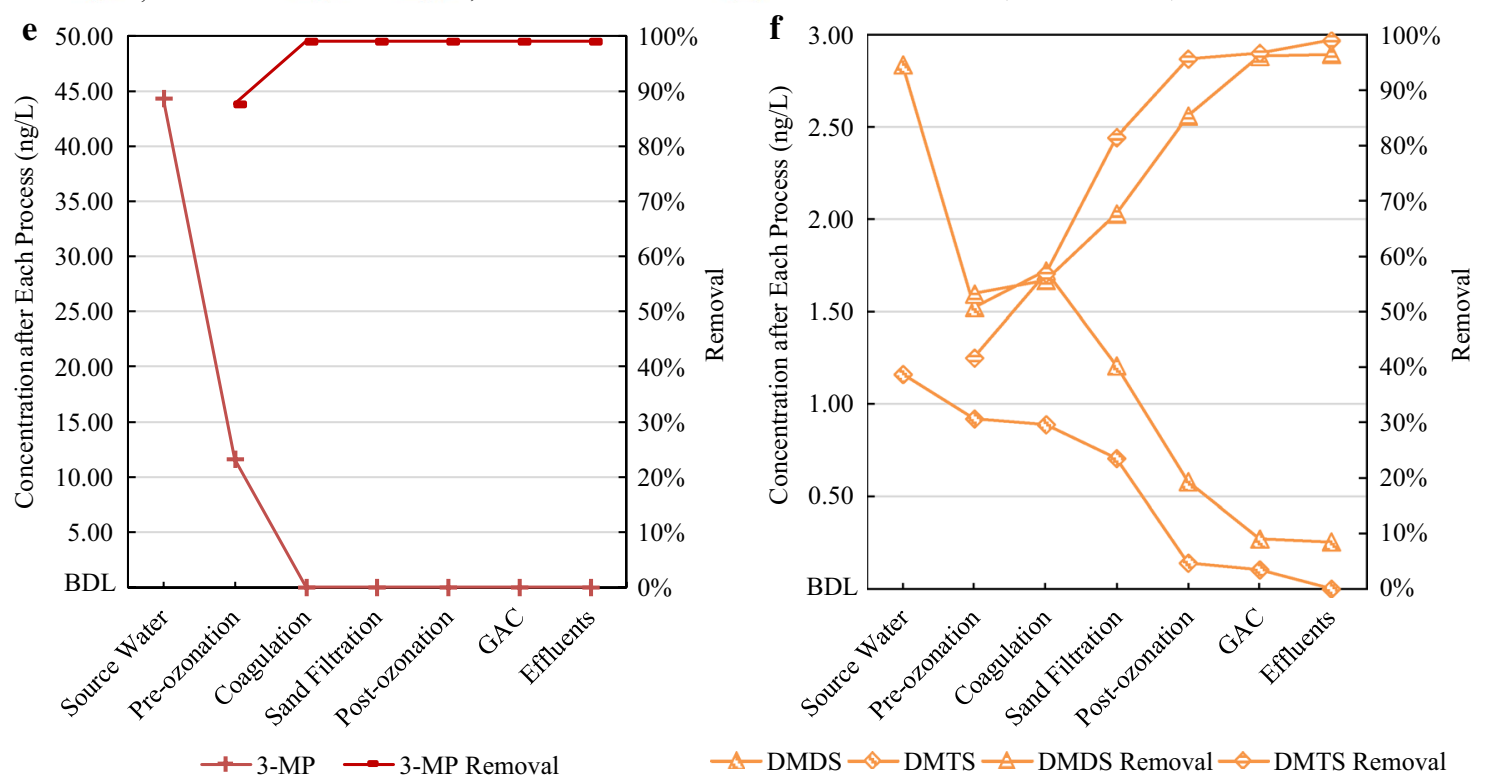

Fig. 6 Concentration after each process and average removal shown with corresponding groups. Samples were collected monthly from July 2018 to December 2018 for verification of treatment efficiency. Since 2-MP (phenol) was only detected in two samples and hexanal (aldehyde) and EB (benzene) were not detected in all source water samples, they were not shown in this figure 
BA) were removed at greater than $99 \%$ and $75 \%$, respectively, with the effluent concentrations at below their corresponding OTCs (Fig. 6c). Benzene (1,4-DCB) was removed at $67 \%$, however, the effluent concentration was $4.68 \mathrm{ng} \mathrm{L}^{-1}$, which is significantly less than its threshold value (4500 $\mathrm{ng} \mathrm{L}^{-1}$ ) (Fig. 6d). Pre-ozonation in combination with coagulation showed an excellent removal efficiency for 3-MP (phenol). A greater than 99\% reduction was observed with 3-MP removed to below the detection limit (Fig. 6e). Removal of DMDS and DMTS (thioethers) was approximately $60 \%$ after pre-ozonation while after post-ozonation this removal increased to greater than $85 \%$ and further improved to greater than $95 \%$ after GAC (Fig. 6f); their concentrations in the effluents were $0.25 \mathrm{ng} \mathrm{L}^{-1}$ and below detection limit, respectively. The investigated odorants were effectively removed to below their OTCs in the effluents. Overall, the treatment train after optimization is a great solution for complex odor control.

\section{Conclusions}

This study investigated the fate of the odorants in an existing WTP. The effectiveness of the current treatment units was evaluated and the optimal strategy to resolve the complex odor issue was explored. 2-MIB and BCIE were observed to be the major contributors of the musty/ earthy and chemical/septic odors, respectively. The application of post-ozonation was the key for improving the odorant removals. With a $1.5 \mathrm{mg} \mathrm{\textrm {L } ^ { - 1 }}$ dosage of postozonation, all odorants were removed below the OTCs. When applying a $1 \mathrm{mg} \mathrm{L}^{-1}$ post-ozonation dosage, by combining GAC, the complex odor issue was well controlled regardless of the odorant concentrations in the influents. The optimal and cost-effective treatment train for a promising complex odor control involved a $1 \mathrm{mg}$ $\mathrm{O}_{3} \mathrm{~L}^{-1}$ pre-ozonation in combination with coagulation, sedimentation, and sand filtration, followed by a postozonation with a dosage of $1 \mathrm{mg} \mathrm{O} \mathrm{O}^{-1}$, and a GAC process (EBCT: $14 \mathrm{~min}$ ); this solution was verified in an extended 6-month study where all the odorants were removed simultaneously.

\footnotetext{
Abbreviations

-OH: Hydroxyl group; 1,4-DCB: 1,4-Dichloro-benzene; 2-MIB: 2-Methylisoborneol; 2-MP: 2-Methyl-phenol; 3-MP: 3-Methyl-phenol; BA: Benzaldehyde; BCIE: Bis(2-chloroisopropyl) ether; BDL: Blow detection limit; DI: Deionized; DMDS: Dimethyl disulfide; DMTS: Dimethyl trisulfide; EB: Ethylbenzene; EBCT: Empty bed contact time; FPA: Flavor profile analysis; GAC: Granular activated carbon; GC-MS/MS: Gas chromatography tandem mass spectrometry; GSM: Geosmin; $\mathrm{KMnO}_{4}$ : Potassium permanganate; $\mathrm{K}_{3}$ : $\mathrm{O}_{3}$ rate constant; $\mathrm{NaCl}$ : Sodium chloride; $\mathrm{Na}_{2} \mathrm{SO}_{4}$ : Anhydrous sodium sulfate; $\mathrm{NOM}$ : Natural organic matter; OAV: Odor activity value; $\mathrm{OH} \cdot:$ Hydroxyl radical; OTC: Odor threshold concentration; SPME: Solid phase microextraction; TOC: Total organic carbon; WTP: Water treatment plant; XCD: Xin Che Dun.
}

\section{Acknowledgements}

The authors wish to thank Xiaoxiao Fan and Jianping Lu from Xin Che Dun Waterworks for the partial support of this study.

\section{Authors' contributions}

PX designed the experiments, analyzed the data, and wrote the paper. SYZ, HY, LJ and ZW mainly performed the FPA of typical odorants. DQY, JWY and DZ reviewed and edited the manuscript. All authors read and approved the final manuscript.

\section{Funding}

The authors gratefully acknowledge the support by the "125" Major Science and Technology Program for Water Pollution Control and Treatment (No. 2015ZX07406001), the "135" Major Science and Technology Program for Water Pollution Control and Treatment (No. 2017ZX07207004) and Shanghai Science and Technology Commission (No. 19XD1430800).

\section{Availability of data and materials \\ Not applicable.}

Ethics approval and consent to participate

Not applicable.

\section{Consent for publication}

Not applicable.

\section{Competing interests}

The authors declare that they have no competing interests.

\section{Author details}

${ }^{1}$ Key Laboratory of Yangtze River Water Environment, Ministry of Education, College of Environmental Science and Engineering, Tongji University, Shanghai 200092, China. ${ }^{2}$ Shanghai National Engineering Research Center of Urban Water Resources Co., Ltd., Shanghai 200082, China. ${ }^{3}$ Key Laboratory of Drinking Water Science and Technology, Research Center for Eco-Environmental Sciences, Chinese Academy of Sciences, Beijing 100085, China.

Received: 5 December 2019 Accepted: 22 February 2020

Published online: 25 March 2020

\section{References}

1. Ahn H, Chae S, Kim S, Wang C, Summers RS (2007) Efficient taste and odour removal by water treatment plants around the Han River water supply system. Water Sci Technol 55(5):103-109

2. Antonopoulou M, Evgenidou E, Lambropoulou D, Konstantinou I (2014) A review on advanced oxidation processes for the removal of taste and odor compounds from aqueous media. Water Res 53:215-234

3. APHA, AWWA, WEF (2005) Standard Methods for the Examination of Water and Wastewater, twenty-first ed. APHA, Washington, DC

4. Atasi KZ, Chen T, Huddleston J, Young CC, Suffet IH (1999) Factor screening for ozonating the taste- and odor-causing compounds in source water at Detroit, USA. Water Sci Technol 40(6):115-122

5. ATSDR (Agency for Toxic Substances and Disease Registry) (1999) Toxicological profile for ethylbenzene. Public Health Service, U.S. Department of Health and Human Services, Atlanta

6. Bechard MJ, Rayburn WR (1979) Volatile organic sulfides from freshwater algae. J Phycol 15(4):379-383

7. Broséus R, Vincent S, Aboulfadl K, Daneshvar A, Sauvé S, Barbeau B, Prévost M (2009) Ozone oxidation of pharmaceuticals, endocrine disruptors and pesticides during drinking water treatment. Water Res 43(18):4707-4717

8. Bruce D, Westerhoff P, Brawley-Chesworth A (2002) Removal of 2-methylisoborneol and geosmin in surface water treatment plants in Arizona. J Water Supply Res Technol AQUA 51(4):183-197

9. Caron F, Kramer JR (1994) Formation of volatile sulfides in freshwater environments. Sci Total Environ 153(3):177-194

10. Chen S, Dong B, Gao K, LiT (2019) Pilot study on advanced treatment of geosmin and 2-MIB with $\mathrm{O}_{3} /$ GAC. Water Sci Technol Water Supply 19(4):1253-1263 
11. Cheng X, Wodarczyk M, Lendzinski R, Peterkin E, Burlingame GA (2009) Control of DMSO in wastewater to prevent DMS nuisance odors. Water Res 43(12):2989-2998

12. Davi ML, Gnudi F (1999) Phenolic compounds in surface water. Water Res 33(14):3213-3219

13. Doederer K, De Vera GA, Espino MP, Pype M-L, Gale D, Keller J (2018) MIB and geosmin removal during adsorption and biodegradation phases of GAC filtration. Water Sci Technol Water Supply 18(4):1449-1455

14. Fishbein $L$ (1979) Potential halogenated industrial carcinogenic and mutagenic chemicals III. Alkane halides, alkanols and ethers. Sci Total Environ 11(3):223-257

15. Geer Wallace MA, Pleil JD, Mentese S, Oliver KD, Whitaker DA, Fent KW (2017) Calibration and performance of synchronous SIM/scan mode for simultaneous targeted and discovery (non-targeted) analysis of exhaled breath samples from firefighters. J Chromatogr A 1516:114-124

16. Ginzburg B, Chalifa I, Gun J, Dor I, Hadas O, Lev O (1998) DMS formation by dimethylsulfoniopropionate route in freshwater. Environ Sci Technol 32(14):2130-2136

17. Guo Q, Yang K, Yu J, Wang C, Wen X, Zhang L, Yang M, Xia P, Zhang D (2016) Simultaneous removal of multiple odorants from source water suffering from septic and musty odors: verification in a full-scale water treatment plant with ozonation. Water Res 100:1-6

18. Guo Q, Yu J, Yang K, Wen Z, Zhang H, Yu Z, Li H, Zhang D, Yang M (2016) Identification of complex septic odorants in Huangpu River source water by combining the data from gas chromatography-olfactometry and comprehensive two-dimensional gas chromatography using retention indices. Sci Total Environ 556:36-44

19. Guo Q, Yu J, Su M, Wang C, Yang M, Cao N, Zhao Y, Xia P (2019) Synergistic effect of musty odorants on septic odor: verification in Huangpu River source water. Sci Total Environ 653:1186-1191

20. Ho L, Newcombe G, Croué J-P (2002) Influence of the character of NOM on the ozonation of MIB and geosmin. Water Res 36(3):511-518

21. IEH (Institute of environment and Health) (2014) National assessment of the risks to water supplies posed by low taste and odour threshold compounds, http://dwi.defra.gov.uk/research/completed-research/repor ts/DWI70-2-281.pdf. Accessed 15 Aug 2019

22. Ito T, Miyaji T, Nakagawa T, Tomizuka N (2007) Degradation of dimethyl disulfide by Pseudomonas fluorescens strain 76. Biosci Biotechnol Biochem $71(2): 366-370$

23. Izaguirre G, Taylor WD (1998) A Pseudanabaena species from Castaic Lake, California, that produces 2-methylisoborneol. Water Res 5:1673-1677

24. Joe WH, Choi IC, Baek YA, Choi YJ, Park GS, Yu MJ (2007) Advanced treatment for taste and odour control in drinking water: case study of a pilot scale plant in Seoul, Korea. Water Sci Technol 55(5):111-116

25. Jüttner $F$ (1992) Flavour compounds in weakly polluted rivers as a means to differentiate pollution sources. Water Sci Technol 25(2):155-164

26. Jüttner F, Watson SB (2007) Biochemical and ecological control of geosmin and 2-methylisoborneol in source waters. Appl Environ Microbiol 73(14):4395-4406

27. Kim T-K, Moon B-R, Kim T, Kim M-K, Zoh K-D (2016) Degradation mechanisms of geosmin and 2-MIB during UV photolysis and UV/chlorine reactions. Chemosphere 162:157-164

28. Kirisits MJ, Snoeyink VL, Kruith of JC (2000) The reduction of bromate by granular activated carbon. Water Res 34(17):4250-4260

29. Larocque RL (1999) Ozone applications in Canada-a state of the art review. Ozone Sci Eng 21(2):119-125

30. Li L, Zhu C, Xie C, Shao C, Yu S, Zhao L, Gao N (2018) Kinetics and mechanism of Pseudanabaena cell inactivation, 2-MIB release and degradation under exposure of ozone, chlorine and permanganate. Water Res 147:422-428

31. Li L, Yang S, Yu S, Zhang Y (2019) Variation and removal of 2-MIB in fullscale treatment plants with source water from Lake Tai, China. Water Res 162:180-189

32. Lin C, Nguyen KA, Vu CT, Senoro D, Villanueva MC (2017) Contamination levels and potential sources of organic pollution in an Asian river. Water Sci Technol 76(9):2434-2444

33. Lin T-F, Wong J-Y, Kao H-P (2002) Correlation of musty odor and 2-MIB in two drinking water treatment plants in South Taiwan. Sci Total Environ 289(1-3):225-235
34. Ma L, Wang C, Li H, Peng F, Yang Z (2018) Degradation of geosmin and 2-methylisoborneol in water with UV/chlorine: influencing factors, reactive species, and possible pathways. Chemosphere 211:1166-1175

35. Ni J-Q, Robarge WP, Xiao C, Heber AJ (2012) Volatile organic compounds at swine facilities: a critical review. Chemosphere 89(7):769-788

36. Ntampou X, Zouboulis Al, Samaras P (2006) Appropriate combination of physico-chemical methods (coagulation/flocculation and ozonation) for the efficient treatment of landfill leachates. Chemosphere 62(5):722-730

37. Oloibiri V, Ufomba I, Chys M, Audenaert WTM, Demeestere K, Van Hulleab SWH (2015) A comparative study on the efficiency of ozonation and coagulation-flocculation as pretreatment to activated carbon adsorption of biologically stabilized landfill leachate. Waste Manag 43:335-342

38. Park G, Yu M, Koo J-Y, Joe WH, Kim H (2006) Oxidation of geosmin and MIB in water using $\mathrm{O} 3 / \mathrm{H}_{2} \mathrm{O}_{2}$ : kinetic evaluation. Water Sci Technol Water Supply 6(2):63-69

39. Park H, Kim T-Y, Woo D, Cho Y-S (2015) Comparison of $\mathrm{O}_{3}+\mathrm{GAC}_{1} \mathrm{O}_{3}+$ $\mathrm{H}_{2} \mathrm{O}_{2}+\mathrm{GAC}$, and GAC unit operation on natural organic matter and taste and odor causing compounds removal using a pilot plant study. Water Sci Technol Water Supply 15(6):1383-1395

40. Peter A, Von Gunten U (2007) Oxidation kinetics of selected taste and odor compounds during ozonation of drinking water. Environ Sci Technol 41(2):626-631

41. Scott BA, Pepper IL (2010) Water distribution systems as living ecosystems: impact on taste and odor. J Environ Sci Health Part A Toxic/Hazard Subst Environ Eng 45(7):890-900

42. Smet $E$, Van Langenhove $H$ (1998) Abatement of volatile organic sulfur compounds in odorous emissions from the bio-industry. Biodegradation 9(3-4):273-284

43. Shareefdeen Z, Herner B, Webb D, Wilson S (2003) Biofiltration eliminates nuisance chemical odors from industrial air streams. J Ind Microbiol Biotechnol 30(3):168-174

44. Srinivasan R, Sorial GA (2011) Treatment of taste and odor causing compounds 2-methyl isoborneol and geosmin in drinking water: a critical review. J Environ Sci 23(1):1-13

45. Summers RS, Kim SM, Shimabuku K, Chae S-H, Corwin CJ (2013) Granular activated carbon adsorption of MIB in the presence of dissolved organic matter. Water Res 47(10):3507-3513

46. Sun D, Yu J, An W, Yang M, Chen G, Zhang S (2013) Identification of causative compounds and microorganisms for musty odor occurrence in the Huangpu River, China. Acad J Environ Sci 25(3):460-465

47. Suurnäkki S, Gomez-Saez GV, Rantala-Ylinen A, Jokela J, Fewer DP, Sivonen K (2015) Identification of geosmin and 2-methylisoborneol in cyanobacteria and molecular detection methods for the producers of these compounds. Water Res 68:56-66

48. Tung S-C, Li W-J (2011) Study on oxidation kinetics of dissolved 2-methylisoborneol. Sustain Environ Res 21(6):395-400

49. U.S. EPA (2010) Dimethyl disulfide fact sheet. https://www3.epa.gov/pesti cides/chem_search/reg_actions/pending/fs_PC-029088_09-Jul-10.pdf. Accessed 15 Aug 2019

50. U.S. EPA (2015) Provisional peer-reviewed toxicity values for benzaldehyde. https://cfpub.epa.gov/ncea/pprtv/documents/Benzaldehyde.pdf. Accessed 15 Sept 2019

51. U.S. EPA (2016) Harmful algal bloom and drinking water. https://www. epa.gov/sites/production/files/2016-11/documents/harmful_algal blooms_and_drinking_water_factsheet.pdf. Accessed 15 Aug 2019

52. USGS (2015) National field manual for the collection of water-quality data. https://water.usgs.gov/owq/FieldManual/compiled/NFM_compl ete.pdf. Accessed 15 Aug 2019

53. Vega E, Martin MJ, Gonzalez-Olmos R (2014) Integration of advanced oxidation processes at mild conditions in wet scrubbers for odourous sulphur compounds treatment. Chemosphere 109:113-119

54. Wang C, Yu J, Guo Q, Zhao Y, Cao N, Yu Z, Yang M (2019) Simultaneous quantification of fifty-one odor-causing compounds in drinking water using gas chromatography-triple quadrupole tandem mass spectrometry. J Environ Sci 79:100-110

55. Watson SB, Monis P, Bake P, Giglio S (2016) Biochemistry and genetics of taste- and odor-producing cyanobacteria. Harmful Algae 54:112-127

56. WHO (2011) Management of cyanobacteria in drinking-water supplies: information for regulators and water supplies. https://www.who.int/ 
water_sanitation_health/dwq/cyanobacteria_in_drinking-water.pdf. Accessed 15 Aug 2019

57. Westerhoff P, Nalinakumari B, Pei P (2006) Kinetics of MIB and geosmin oxidation during ozonation. Ozone Sci Eng 28(5):277-286

58. Westerhoff P, Yoon Y, Snyder S, Wert E (2005) Fate of endocrine-disruptor, pharmaceutical, and personal care product chemicals during simulated drinking water treatment processes. Environ Sci Technol 39(17):6649-6663

59. Xie P, Ma J, Liu W, Zou J, Yue S, Li X, Wiesner MR, Fang J (2015) Removal of 2-MIB and geosmin using UV/persulfate: contributions of hydroxyl and sulfate radicals. Water Res 69:223-233

60. Yang K, Yu J, Guo Q, Wang C, Yang M, Zhang Y, Xia P, Zhang D, Yu Z (2017) Comparison of micropollutants' removal performance between preozonation and post-ozonation using a pilot study. Water Res 111:147-153

61. Yu J, An W, Cao N, Yang M, Gu J, Zhang D, Lu N (2014) Quantitative method to determine the regional drinking water odorant regulation goals based on odor sensitivity distribution: illustrated using 2-MIB. J Environ Sci China 26(7):1389-1394

62. Yu JW, Zhao YM, Yang M, Lin T, Guo ZH, Gu JN, Li S, Han W (2009) Occurrence of odour-causing compounds in different source waters of China. J Water Supply Res Technol AQUA 58(8):587-594

63. Zamyadi A, Henderson R, Stuetz R, Hofmann R, Ho L, Newcombe G (2015) Fate of geosmin and 2-methylisoborneol in full-scale water treatment plants. Water Res 83:171-183
64. Zhang K, Lin TF, Zhang T, Li C, Gao N (2013) Characterization of typical taste and odor compounds formed by Microcystis aeruginosa. J Environ Sci 25(8):1539-1548

65. Zhang S, Gitungo S, Axe L, Dyksen JE, Raczko RF (2016) A pilot plant study using conventional and advanced water treatment processes: evaluating removal efficiency of indicator compounds representative of pharmaceuticals and personal care products. Water Res 105:85-96

66. Zhang N, Xu B, Qi F, Kumirska J (2016) The occurrence of haloanisoles as an emerging odorant in municipal tap water of typical cities in China. Water Res 98:242-249

67. Zhang X-J, Chen C, Ding J-Q, Hou A, Li Y, Zhang B-N, Su X-Y, Xu Y-J, Laws EA (2010) The 2007 water crisis in Wuxi, China: analysis of the origin. J Hazard Mater 182(1-3):130-135

68. Zhu IX, Wang J, Wieland A (2015) Ozone-enhanced biologically active filtration for wastewater reuse. J Am Water Works Assoc 107(12):E685-E692

\section{Publisher's Note}

Springer Nature remains neutral with regard to jurisdictional claims in published maps and institutional affiliations.

\section{Submit your manuscript to a SpringerOpen ${ }^{\circ}$ journal and benefit from:}

- Convenient online submission

- Rigorous peer review

- Open access: articles freely available online

- High visibility within the field

- Retaining the copyright to your article

Submit your next manuscript at $\mathbf{s p r i n g e r o p e n . c o m ~}$ 